\title{
Rhythmic Activities Based on Traditional West Kalimantan Culture
}

\author{
Fitriana Puspa Hidasari ${ }^{1 *}$, Muhammad Fachrurrozi Bafadal ${ }^{2}$, and Andika Triansyah ${ }^{3}$ \\ ${ }^{1,2,3}$ Department of Sport Science, Universitas Tanjungpura, Pontianak, Indonesia \\ *Corresponding author. Email: fitriana.puspa@fkip.untan.ac.id
}

\begin{abstract}
Screen based technology leaves homework for parents and educational institutions. If this perpetual behavior continues, the child will lose a period in which all aspects of his development rapidly, one of which is that physically activity becomes limited, physical activity is generally formed in childhood aged 2-5 years. This period is called golden age period where the development of physical aspects becomes part of the development that needs special attention. The purpose of this research is to create rhythmic activities in the form of rhythmic gymnastics based on the traditional culture of West Kalimantan to provide guidance, shape variants, and enrich the movement activities for early childhood which are based on local wisdom values. Research uses research and development methods where research activities will produce a new product. The population and sample in this study were PAUD/TK in the city of Pontianak. The results of the study are the products of rhythmic activity can be accepted with a percentage rate of $100 \%$ (very acceptable) by the user, in the limited scale test the average rating obtained by the user is $86 \%$ (very good) and the broad scale test stage is obtained an average yield of $90 \%$ (very good).
\end{abstract}

Keywords: Rhythmic Activities, West Kalimantan Culture, Early Childhood

\section{INTRODUCTION}

The use of screen-based technology in early childhood is very often found, based on the findings in Pontianak there are two activities to use screen-based technology, 1). Used to play online and offline games, 2). Watch Youtube [1], in the second activity, children's viewing content varies depending on gender, there are watching superhero animated films, children's songs, children's play activities, and even watching soap operas. Some studies also show something similar like a study that released data from 170 samples of children in a Private Kindergarten in Pontianak City found 166 students have used a gadget with an intensity of 30 minutes to 5 hours per day [2]. Other research results released $94 \%$ of parents stated that their children used to use gadgets to play games, $63 \%$ of children spent a maximum of 30 minutes playing a game and $15 \%$ of parents stated that children played games for 30-60 minutes and the rest used gadgets more than 60 minutes [3].

The rampant use of screen-based technology that is too long in children will divert the child's attention from physical activity, because the addicted nature of using screen-based technology will cause several problems including not achieving optimal overall development which includes cognitive, social, emotional, and motor development. The low active physical activity in children is known as sedentary behavior, ie behavior with very low energy expenditure where the dominant activity is sitting or lying down [4].

The stakeholders, the government, educational institutions, and the private sector cannot be resistant to this because the flow of technology and the changing times will not be unstoppable. Prohibiting children from using screen-based technology will make children more curious. What is important to manage is the intensity of fair use, content viewed according to age and gender, and the use of screen-based technology balanced with physical activity in children. Physical activity in children will support aspects of natural development that have specific characteristics such as 1). High curiosity, 2) love to fantasize and imagine, 3) potential time for learning, 4) egocentric period, 5) and have a short span of concentration power [5].

Early childhood has a very high learning ability, seen from the high level of curiosity of the child. Children will try to find out something interesting according to their perception. Children are also more creative than the previous stage in terms of learning abilities and have more ability to express themselves as seen from children who have started to have the ability to describe something that is around them and start doing challenging activities. The characteristics above should be a guide for parents and educational institutions to focus more on children's activities in aspects of physical activity or learning movement. 
Physical activity is a learning experience given to children. Forms of physical activity can vary, one of which is to provide a learning experience of movement that is planned, structured, has clear goals and a short duration of activity in accordance with the power of concentration in early childhood is short.

In childhood the growth of height and weight relatively decreases in speed compared to the previous period. Height and weight have both increased, but the percentage increase has been different. The percentage increase in height can reach two times. Because of this, children generally tend to look slim or thin. In forming a height increase the percentage of foot length growth is greater than togok growth. This is why children need more physical activity, because by doing physical activity it will stimulate growth and development. But the presence of the flow of technology media began to shift the physical activity of children marked by several findings / studies relating to children's activities with screen-based technology media.

Physical activity in different forms is very important for the growth and health of children. Children need physical activity to be able to grow and develop normally, maintain fitness and health, develop physical skills and behaviors that will be carried into adulthood [6]. Physical skills also include a child's body control including walking, running, jumping, jumping on one foot, jumping on two legs, throwing and balance [7].

Based on the above problems, the researcher intends to design a physical activity accompanied by music and based on local culture in West Kalimantan. What is meant by the local culture of West Kalimantan is traditional activities or dances and music from ethnic Malays and Dayaks [8]. Researcher's consideration is that rhythmic activity is very suitable for early childhood by providing a learning experience of motion accompanied by music with the aim of providing knowledge about local culture. By doing rhythmic activities the child will learn coordination and synchronization of movement and music while the child will unconsciously learn local culture because at an early age the child is programmed to be in the imitation / imitation phase, rhythmic activity is also suitable for reducing the sedentary behavior of children. In 2013 it was found as many as $30-65 \%$ of children used their time for sedentary activities [9].

Rhythmic activity will strengthen the foundation of positive characters that are instilled early on. This activity can develop more than one intelligence, namely children's kinesthetic, cognitive and musical intelligence.
Rhythmic activities that are designed will be adjusted to the stage of development of the child's age, using audiovisual media so that children are interested in learning and make an eyecatching display so that children enjoy while doing activities so that the cognitive aspects of the child will easily absorb the information conveyed because of activities with pleasure while studying. The target of this research is early childhood, preferably at the paud / kindergarten level. Activities will be carried out in stages and with good supporting facilities.

The purpose of this study is to produce rhythmic gymnastic activity products based on local culture in West Kalimantan for early childhood. The product will be packaged in a video and equipped with a manual for implementing activities. It is expected that the results of this research will benefit the product users both within the educational institutions and other relevant parties, for the development of Physical Education and Early Childhood Education that is being encouraged to give birth to future gold generations that are advanced and continue to uphold values - the value of local culture.

\section{METHODS}

\section{A. Research Design}

Research carried out is a product development activity so this type of research includes research and development (R\&D). In the $R \& D$ research model chosen, the research and development model developed by Borg \& Gall includes 1) potentials and problems, 2) literature study and information gathering, 3) designing the initial draft of the product, 4) design validation, 5) design revision, 6 ) manufacturing of products, 7) initial (limited) field tests, 8) initial product revisions, 9) main field tests, 10) major product revisions, 11) operational field tests, 12) final product revisions, and 13) dissemination and implementation [10].

This research was conducted in 7 (seven) months. The results of the research are in the form of products containing rhythmic activities based on traditional culture of West Kalimantan, which are equipped with manuals and videos that explain the processes and procedures for implementing activities.

\section{B. Development Procedure}

The research and development model developed by Borg and Gall will be adapted according to the needs and objectives of this study. 


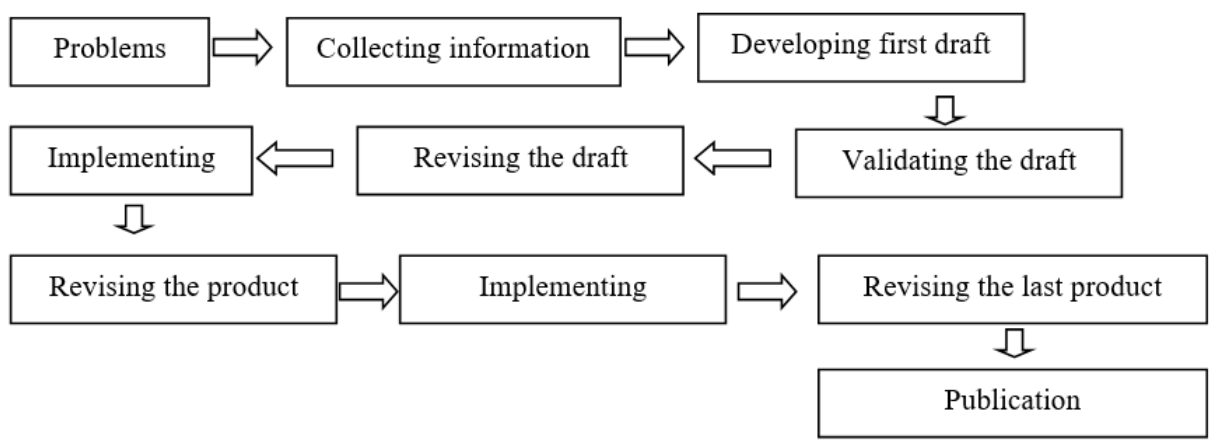

Fig.1. Research flow

\section{Data Collection Techniques and Tools}

Data collection techniques in the early stages are the study of literature and information gathering using; 1). observation techniques, 2). indirect communication, and 3). documentation.

At the design and development stages, the respondents' product drafts are divided into two groups. The first group is the experts (expert judgment) and PAUD / TK teachers, the first group is intended to assess the suitability of the draft product made, evaluate the product development process, and provide advice on the draft product that has been made. In the first group, data collection techniques were applied using indirect communication techniques.

The second group is Paud or kindergarten students in Pontianak City, the second group is intended for product acceptance testing. In the second group, data collection techniques were applied using indirect communication and documentation techniques.

Data collection tools at an early stage are literature studies and information gathering using; 1). Observation sheet to find out the situation in the field, 2). a box for teachers and students, and 3). documentation.

\section{Data Analysis Techniques}

In the initial stages of data analysis, qualitative descriptive analysis will be used. Qualitative descriptive analysis is used because it can interpret information obtained from field observations using observation sheets and interviews with Paud teachers or kindergartens in Pontianak city.

At the design and development stages of the product draft several methods will be used namely; 1) in the validation stage of the initial product draft design used quantitative descriptive analysis to interpret the assessment data from experts and qualitative descriptive analysis is used to interpret the advice data from experts, 2) at the field trial stage (development) a quantitative descriptive analysis approach will be used.

\section{RESULT AND DISCUSSION}

Based on the stages of research that have been carried out, the results are presented as follows:

\section{E. Phase I}

1. Stage of potential and problems

At this stage, it was found (a) the gap between the theory of early childhood development with the field conditions, (b) the gap between the intensity of active and passive activities in children, (c) the programmatic rhythmic activity based on West Kalimantan's culture in early childhood education institutions.2. Tahap studi literatur dan pengumpulan informasi

At this stage found (a) TPPA (Child Development Achievement Level) age group 4-6 years, (b) various physical activity models to optimize gross motoric children, (c) distinctive cultures of West Kalimantan that have been officially registered at BPNB ( Balai Preserving Cultural Values) Ministry of Education and Culture as non-cultural cultural heritage.

3. Initial product design stage

At this stage, an initial draft / design of the product is produced in the form of a rhythmic gymnastics video covering cultural suitability that will be adapted to the form of rhythmic activity, rhythmic movement suitability with the Level of Achievement of Child Development in the age group of 4-6 years, duration of activity, and appropriate accompaniment music.

4. Design validation stage

At this stage the researcher together with expert judgment reviewed the draft that had been made in the FGD activities and then proceeded to the stage of limited public testing. At this stage there is a change in the tempo of the music, added prayer activities and opening greetings at the beginning of gymnastics activities and closing greetings at the end of gymnastics.

Following are the results of the assessment at the design validation stage:

Table.1. The results of Expert's assessment of the implementation of rhythmic activities based on West Kalimantan culture

\begin{tabular}{|c|c|c|c|}
\hline Rating Indicator & Score & $\begin{array}{c}\text { Percentage } \\
(\%)\end{array}$ & $\begin{array}{c}\text { Rating } \\
\text { Category }\end{array}$ \\
\hline Warming up movement & 43 & 89.5 & Very Good \\
\hline Core Movement & 44 & 91.6 & Very Good \\
\hline Cooling down movement & 42 & 87.5 & Very Good \\
\hline
\end{tabular}


Based on the judgment from expert judgment, the product is ready for field testing TK/PAUD.

F. Phase II

At this stage, a limited test was conducted on one kindergarten in the Southeast Pontianak region on October 1, 2019. The results of this stage were: (a) product evaluation by the user, (b) product acceptance by the user, (b) user suggestions. Respondents involved at this stage were 2 teachers and 34 students.

The following presents the results of assessment data at the limited test stage, at this stage involving 2 teachers as field assessors:

Table.2. The results of Expert's assessment of the implementation of rhythmic activities based on West Kalimantan culture

\begin{tabular}{|c|c|c|c|}
\hline $\begin{array}{c}\text { Rating } \\
\text { Indicator }\end{array}$ & Score & $\begin{array}{c}\text { Percentage } \\
(\%)\end{array}$ & $\begin{array}{c}\text { Rating } \\
\text { Category }\end{array}$ \\
\hline $\begin{array}{c}\text { Warming up } \\
\text { movement }\end{array}$ & 84 & 87.5 & Very Good \\
\hline $\begin{array}{c}\text { Core } \\
\text { Movement }\end{array}$ & 83 & 86.4 & Very Good \\
\hline $\begin{array}{c}\text { Cooling down } \\
\text { movement }\end{array}$ & 88 & 91.3 & Very Good \\
\hline
\end{tabular}

Table.3. Test results of product acceptance by students

\begin{tabular}{|c|c|c|}
\hline Student responses & Respondents & $\begin{array}{c}\text { Percentage } \\
(\%)\end{array}$ \\
\hline Happy (+) & 34 & 100 \\
\hline Not Happy(-) & 0 & 0 \\
\hline Amount & 34 & 100 \\
\hline
\end{tabular}

6. Product revision phase

Based on the results of assessments and evaluations by the teacher at the limited test stage, at this stage the revised product section is (a) GP (Transition Motion) between warming up to the core stage and core to the cooling down stage, (b) the location of gymnastic activities taking pictures outdoor to improve the quality of the appearance of the image created.

7. Operational trial phase

At this stage operational tests were carried out on three kindergartens. As for what is produced at this stage are: (a) user acceptance of the product, (b) suggestions from users.

The following are presented research data at the operational test stage, at this stage involving 6 practitioners / teachers as field assessors.

Table.4. The results of teacher assessment of the implementation of rhythmic activities based on West Kalimantan culture

\begin{tabular}{|c|c|c|c|}
\hline Rating Indicator & Score & $\begin{array}{c}\text { Percentage } \\
(\%)\end{array}$ & $\begin{array}{c}\text { Rating } \\
\text { Category }\end{array}$ \\
\hline $\begin{array}{c}\text { Warming up } \\
\text { movement }\end{array}$ & 266 & 92.4 & $\begin{array}{c}\text { Very } \\
\text { Good }\end{array}$ \\
\hline Core movement & 249 & 86.4 & $\begin{array}{c}\text { Very } \\
\text { Good }\end{array}$ \\
\hline $\begin{array}{c}\text { Cooling down } \\
\text { movement }\end{array}$ & 250 & 86.8 & $\begin{array}{c}\text { Very } \\
\text { Good }\end{array}$ \\
\hline
\end{tabular}

Tabel.5. Test results of product acceptance by students

\begin{tabular}{|c|c|c|}
\hline $\begin{array}{c}\text { Student } \\
\text { Responses }\end{array}$ & Respondents & $\begin{array}{c}\text { Percentage } \\
(\%)\end{array}$ \\
\hline Happy $(+)$ & 73 & 100 \\
\hline $\begin{array}{c}\text { Not Happy } \\
(-)\end{array}$ & 0 & 0 \\
\hline Amount & 73 & 100 \\
\hline
\end{tabular}

8. Final product revision

ased on the results of assessments and evaluations by teachers at the operational test stage, at this stage the revised product section is (a) Video packaging (packaging).

9. Publication

The final activity of the R and D research is the publication / dissemination of research results. This research was published at the activity: The 1st International Conference on Sport Science, Health, and Tourism (ICoSSHT) in PadangWest Sumatrat.

\section{CONCLUSION}

In conclusion, the products of rhythmic activity can be accepted by the user, in the limited scale test the average rating obtained by the user is very good and the broad scale test stage is obtained an average yield of very good.

\section{REFERENCES}

[1] F. Puspa Hidasari, "Intensitas Penggunaan Gadget Dan Aktivitas Motorik Anak Usia 4-6 Tahun di Kota Pontianak," Altius J. Ilmu Olahraga dan Kesehat., vol. 8, no. 2, pp. 85-91, Nov. 2019.

[2] I. A. Trinika Yulia, Nurfianti A, "Pengaruh Penggunaan Gadget Terhadap Perkembangan Psikososial Anak Usia Prasekolah (3- 6 Tahun) di TK Swasta Kristen Immanuel," Jurnal Proners, 2015. [Online]. Available: http://jurnal.untan.ac.id/index.php/jmkeperawata nFK/article/view/11001/10480. [Accessed: 09Nov-2019].

[3] R. Delima, N. K. Arianti, and B. Pramudyawardani, "Pengembangan Aplikasi Permainan Edukasi Untuk Anak Prasekolah Menggunakan Pendekatan Child Centered Design," J. Inform., vol. 12, no. 1, pp. 13-23, Jun. 2016.

[4] R. R. Pate, J. R. O'Neill, and F. Lobelo, "The Evolving Definition of 'Sedentary," Exerc. Sport Sci. Rev., vol. 36, no. 4, pp. 173-178, Oct. 2008.

[5] F. P. Hidasari, L. Natalia, and Y. Pramana, "Pengembangan Modul Ajar Mata Kuliah Pertumbuhan Dan Perkembangan Motorik 
Berbasis Pembelajaran Inklusi," Jorpres (Jurnal Olahraga Prestasi), vol. 14, no. 1, pp. 34-45, 2018.

[6] T. J. and J. Jurimae, Growth, Physical Activity, And Motor Development in Prepubertal Children. London: CRC Press, 2001.

[7] M. Lloyd, Typical and Atypical Motor Development, vol. 30, no. 4. 2016.

[8] M. B. Santy, "Kearifan lokal dalam budaya daerah kalimantan barat (etnis melayu dan dayak)," J. Penelit. IPTEKS, vol. 2, no. 1, pp. 91-104, 2017.
[9] R. W. Taylor, S. M. Williams, V. L. Farmer, and B. J. Taylor, "Changes in physical activity over time in young children: A longitudinal study using accelerometers," PLoS One, vol. 8, no. 11, pp. 1-7, 2013.

[10]B. and G. W. R. B. J. P. Gall, Educational Research: An Introduction, eighth Edition, Seventh Ed. 2015. 